\title{
東京湾におけるアサリ浮遊幼生の鉛直移動 モデルの構築について
}

\author{
大塚 文和 $1 \cdot$ 川西 利昌 $2 \cdot$ 増田 光一 3 \\ 1正会員 日本大学助教 理工学部海洋建築工学科（干274-8501 千葉県船橋市習志野台7-24-1) \\ E-mail:otsuka.fumikazu@nihon-u.ac.jp \\ 2 日本大学教授 理工学部海洋建築工学科（†274-8501 千葉県船橋市習志野台7-24-1） \\ E-mail:kawanishi@cst.ocean.nihon-u.ac.jp \\ 3正会員 日本大学教授 理工学部海洋建築工学科（干274-8501 千葉県船橋市習志野台7-24-1） \\ E-mail:masuda.koichi@nihon-u.ac.jp
}

\begin{abstract}
東京湾におけるアサリ幼生の観測結果である殻長出現頻度分布を基に、それらを正規分布の重㸚合わせ で近似できるとした混合正規分布と捉え、最小 2 乗法により同時発生個体群（コホート）を抽出すること により、合理的に平均成長速度を推定した。また、その結果を踏まえて、アサリ幼生の発生時の殼長およ び成長速度について個体差を考慮した簡易な幼生成長モデルを構築し、殼長出現頻度分布の観測結果を再 現することにより、成長モデルの妥当性を明らかにした。更に、アサリ幼生の殼長や鉛直移動速度等の個 体差を考慮した鉛直移動モデルを構築し、鉛直 1 次元の基本的な再現シミュレーションを行い、モデルの 妥当性を明らかにした。
\end{abstract}

Key Words : tokyo bay, generation structure, vertical movement, ruditapes philippinarum

\section{1. 緒 言}

東京湾では、干潟・浅場域は埋立などにより大幅に減 少し、現状においては湾内に離散的に存在する状況とな っている。その結果、干潟・浅場に棲むアサリなどの生 物は、埋立地の間に辛うじて残った浅場や人工的に造成 された小規模の海浜などに生息する状況となっている。 しかし、これらの離散的な生息場間で幼生供給を基本と するアサリのネットワークが存在し、アサリの生息にと って重要な役割を担っていることが明らかになりつつあ る。

アサリネットワークについてのこれまでの研究は、粕 谷ら ${ }^{1)}$ 、日向ら ${ }^{2)}$ 、大塚ら ${ }^{3)}$ などの研究があるが、粕谷 ら ${ }^{1)}$ の研究は東京湾内湾全域を対象とした現地調查を中 心としたものであり、日向ら ${ }^{2)}$ や塚ら ${ }^{3}$ の研究は, アサ リ幼生の浮遊シミュレーションを中心としたものであ る。しかし,これらの研究で行われたアサリ幼生の浮遊 シミュレーションは、平面移動のみを考えており、鉛直 移動は考えられていない。

一方、アサリ幼生の鈆直移動についての研究は、石田 $ら^{45)}$ や瀬戸 6) らなどの研究がある。石田ら ${ }^{4}$ は、室内実 験結果を基に、幼生は塩分を感知し、その成長段階にお
ける選択塩分を求めて移動（塩分選択行動）するものと して、塩分移動再現モデルを作成した。しかし、これ を、自ら実海域に適用したシミュレーションを実施した

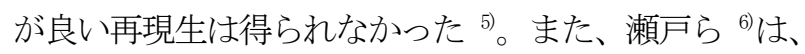
ウバガイとアサリの浮遊幼生を対象に螺旋運動をしなが ら鉛直方向に移動するモデルを作成し、浮遊幼生が着底 に至る過程を検討した。しかし、室内実験の範囲にとど まっており、実海域での適用には至っていない。

今後、アサリネットワークの解明を進めていく上で は、より実際の現象に近い浮遊シミュレーションが求め られており、移動形態として平面移動だけではなく幼生 の発生・浮游から沈降・着底に至る鉛直的な移動を考慮 することが必要であるとともに、アサリ幼生の個体群と しての各種個体差を考慮したより現実的なモデルが必要 と考えられる。

本研究は、アサリ幼生の個体群を対象に殼長組成 解析によりコホート（同時発生個体群）を抽出し、 幼生の成長速度及び発生日を推定した。また、アサ リ幼生の各種個体差および鉛直移動を考慮した基本 的なモデルを構築し、その適用性を検証した。

\section{2. 研究方法}




\section{（1）世代解析}

体長の度数分布を基に、複数の正規分布（同時発生個 体群 ; コホート) に分別する方法は、堤ら ${ }^{7)}$ や赤嶺 ${ }^{8,9}$ などの方法がある。本研究ではアサリ幼生の殼長頻度分 布の解析に赤嶺の方法を使用した。アサリ幼生の殼長出 現頻度分布を Fとし、この出現頻度分布が正規分布の重 ね合わせで構成されていると仮定して、正規分布の組み 合わせで近似するものである。基本式を式(1)～(3) に示 す。

$$
\begin{gathered}
f=\sum_{i=1}^{n} K_{i} \cdot N\left(\mu_{i}, \sigma_{i}, x\right) \\
N=\frac{1}{\sqrt{2 \pi \sigma}}-\exp \left\{-\frac{(x-\mu)^{2}}{2 \sigma^{2}}\right\} \\
d^{2}=\sum_{x-a}^{b} d x^{2}=\sum_{x}(F-f)^{2}
\end{gathered}
$$

ここで、 $N\left(\mu_{\mathrm{i}}, \sigma_{\mathrm{i}}, \mathrm{x}\right)$ は平均值 $\mu_{\mathrm{i}}$ 、標準偏差 $\sigma_{\mathrm{i}}$ と する面積を 1 に正規化した正規分布である。 $K_{i}$ は正 規分布毎の面積を表す。求めるパラメータは、重ね 合わせる正規分布の数を $\mathrm{n}$ とすると $3 \mathrm{n}$ 個であり、 式(3)の $d^{2}$ を最小にするパラメータを Marquart 法 を用いて求めた。

上記の方法を用いて 2 回の殼長出現分布から推定 した同時発生個体群（コホート）の平均值（ $\mu$ ) か ら平均的な成長速度を算出した。また、算出した平 均成長速度を用いて、幼生の発生日を推定した。

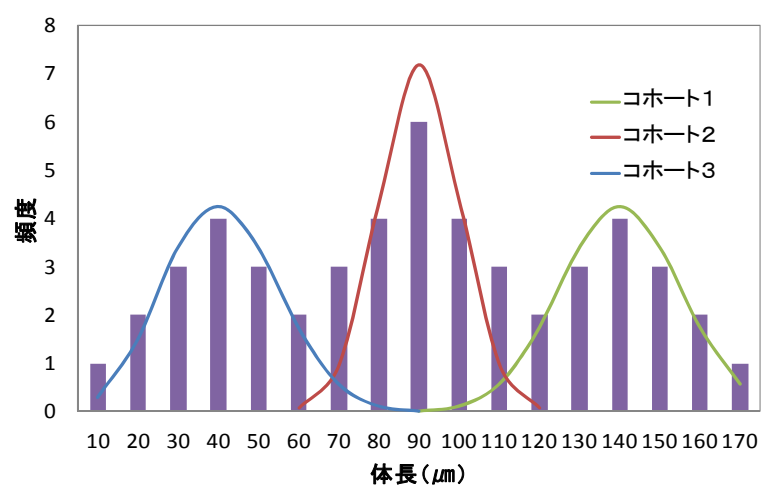

図-1 混合正規分布とコホート抽出

なお、正規分布数 $\mathrm{n}$ については、観測データの解 析結果および尤度から算出する赤池の情報量基準 (AIC) ${ }^{8)}$ を踏まえて決定した。

\section{（2）簡易成長モデルの構築}

アサリの成長モデルに関連する研究としては、着底期 以降を対象に Solidoro ら ${ }^{10)}$ のモデルを東京湾盤洲干潟に
適用した小沼ら ${ }^{11)}$ の研究や同モデルを改良して伊勢湾伊 勢地区に適用した花町ら ${ }^{12)}$ の研究がある。Solidoro ら ${ }^{10)}$ のモデルでは、餌料環境および水温が主な変動要因であ る。また、幼生期の成長については、鳥羽 ${ }^{13}$ の実験的研 究などがある。鳥羽 ${ }^{13}$ の研究では、成長速度は水温に大 きく依存することが明らかとなっており、水温を一定と した実験では時間に関してほぼ線形的な成長が確認され ている。

本研究では、幼生発生から 10 日間程度の短期間の浮 遊幼生期を対象にすることから、鳥羽 ${ }^{13}$ の実験結果の成 長特性を踏まえて、時間に関して線形的な成長を仮定し た。また、環境要因による成長の変化や個体差に係わる 成長速度の変動を乱数で表現することとした。

本研究で用いた簡易成長モデルを式(1)に示す。

$$
L=\alpha \cdot S \cdot T+L_{0}
$$

ここで、 $L$; 幼生の殼長 $(\mu \mathrm{m}) 、 \alpha$; 環境等に係わる 変動（一様乱数）、 $S$; 幼生の成長速度 $(\mu \mathrm{m} / \mathrm{d}) 、 T$, 日数 (day)、 $L_{0}$; 幼生発生時の殼長 $(\mu \mathrm{m})$ である。 幼生発生時の殼長 $L_{0}$ は、個体差を考慮して正規分布 (正規乱数) で与えられるものとした。このとき、平均 值は石田ら ${ }^{4}$ の実験的研究を基に $64 \mu \mathrm{m}$ と設定し、標準 偏差については鳥羽ら ${ }^{14}$ の成熟期の卵細胞径の分布を参 考に、繰り返し計算によって観測データとの整合性から 決定した。また、幼生の成長速度 Sについても、個体差 を考慮して平均成長速度と標準偏差で表す正規分布（正 規乱数) で設定した。平均成長速度については、本研究 の世代解析で求められる平均成長速度を用いた。

上記の簡易成長モデルを用いて、幼生発生時の殼長分 布を成長させ。粕谷ら ${ }^{1)}$ の観測で得られた 2001 年 8 月 2 日及び 6 日の東京湾全域における殸長分布と比較する ことで、成長モデルの適用性を検討した。

\section{（3）鉛直移動モデルの構築}

浮遊幼生は、先に示した成長モデルに従って成長し、 成長に伴って幼生の密度も変化するものとした。そして、 幼生と海水の密度差を起動力とする鉛直移動モデルを構 築した。また、このモデルを用いて、アサリ幼生の一次 元の鉛直分布再現シミュレーションを実施した。 アサリ幼生の鉛直移動速度は、石田 ${ }^{4)}$ らが塩分差を 起動力に定式化した形式に倣い、次式で表した。

$$
V=\beta V \max \tanh \left\{k\left(\gamma \rho_{b}-\rho\right)\right\}
$$

ここで、 $V$; 鉛直移動速度、 $V_{\max }$; 最大移動速度 $(\mathrm{cm} / \mathrm{s}) 、 \gamma$; 補正係数、 $\rho$; ある時刻に幼生がいる 位置における海水密度、 $\rho \mathrm{b}$; ある時刻における幼 生の密度、 $k$; 幼生が周辺海水の密度との差を受け て、どの程度鉛直速度に反映させるかを表す感度パ 
ーラメータ、 $\beta$; 個体差を表現する一様乱数である。

アサリ幼生の成長に伴う密度変化については、瀬 戸ら 6)が室内実験で求めた結果を用いた。また、 $V_{\max }$ は石田ら 4の実験式を基に、成長モデルの形式を考 慮して殼長を変数とする次式でモデル化した。

$$
\begin{aligned}
& V_{\max }=A_{L}\left(L-L_{0}\right)+A_{0} \text { (6) } \\
& \text { ここで、 } A_{\mathrm{L}}=0.016 / \mathrm{Aav} 、 A_{0}=0.0388 \text { であり、Aav； }
\end{aligned}
$$

平均成長速度 $(\mu \mathrm{m} /$ day $) 、 L$; ある時点における幼生殼長 $(\mu \mathrm{m}) 、 L_{0}$; 発生時の平均殼長 $(\mu \mathrm{m})$ である。

海水密度の鉛直構造については、粕谷ら ${ }^{1)}$ の観測 結果を基にモデル化して設定した。式(5)の感度パー ラメータ $k$ について、繰り返し再現シミュレーシ ヨンを行い、決定した。

\section{（4）アサリ幼生の一次元鉛直移動シミュレーショ}

ン

本研究では、先に示した成長モデルおよび鉛直移 動モデルの基本的な適用性を検討するため、一次元 鉛直断面での簡易シミュレーションを行った。

アサリ幼生の鉛直位置は、計算時間間隔 $\Delta \mathrm{T}$ として次 式で表した。

$$
Z_{T+\Delta T}=Z_{T}+(W+V) \Delta T+R
$$

ここで、 $Z_{T}$ 及び $Z_{T+\Delta T}$ は、それぞれ時刻 $\mathrm{T}$ 及び $\mathrm{T}+\Delta \mathrm{T} に お け る$ 鉛直位置である。また、W、 $V$ はそれぞれ幼生の鉛直方向流速、幼生の鉛直移動速度で あり、Rは拡散項である。本研究では、成長モデルおよ び鉛直移動モデルの基本的な適用性を明らかにするため、 対象空間 (東京湾) を 1 次元化しており、 $W$ と $R$ につ いては考慮していない。なお、計算時間間隔を示寸 $\Delta \mathrm{T}$ は,繰り返し計算を行い、再現性を考慮して1時間とし た。また、このとき、鉛直方向は $1 \mathrm{~m}$ 毎の層に分割して 計算した。

式(4)〜(7)を用いて、粕谷ら ${ }^{1)}$ の観測結果を再現対象 として、一様乱数 $\alpha$ と $\beta$ を時間ステップ毎に変化させて アサリ幼生の一次元鉛直移動シミュレーションを実施し、 成長モデル及び鉛直移動モデルの基本的な再現生を検討 した。

\section{3. 世代解析によるコホートの抽出・検討}

図ー 2 および図 -3 に観測結果から作成した幼生殼 長頻度分布および世代解析によるコホート抽出結果を 示す。図- 2 および図-3における幼生頻度分布は、 粕谷ら ${ }^{6}$ の東京湾全域を対象にした観測結果より作成
したアサリ幼生の殼長出現頻度分布であり、図一 2 が 2001 年 8 月 2 日の観測結果、図- 3 は 4 日後の 8 月 6 日の観測結果である。この分布の特徵は、図ー 2 では 明確ではないが、図一 3 では見られるように幼生の出 現が多峰形を形成していることであり、これらを正規 分布が重祆合わさった混合正規分布として、式(1)〜

（3）を用いて世代解析を行った。

図一 2 および図－3に示寸正規分布は、それぞれ同 時に産卵された個体群（コホート）を表わしていると 考え、それぞれの平均值、標準偏差および個体数に対 応する面積を算定し、整理した。この場合において、 世代解析における正規分布（コホート）の数について は、粕谷ら ${ }^{6)}$ の解析結果あるいは尤度から算定する $\mathrm{A}$ I Cを基に決定した。

図一2（8月 2 日）におけるコホートの数について は、粕谷らが整理した幼生の水平分布によると当日は 三枚洲〜羽田沖、市原前面〜盤洲干潟周辺および富津 付近の 3 海域程度で幼生の出現密度が顕著に高い傾向 が見られることを踏まえ、観測出現頻度と世代解析に よる抽出コホートの重祆合わせの整合性を検討して判 断した。また、図一 3 に示寸 8 月 6 日におけるコホー 卜の数については、観測結果の幼生出現頻度（平面） 分布からでは幼生発生群が捉えにくく、8月 2 日にお けるコホート数を踏まえて、コホート数が $3 、 4$ お び5の場合について赤嶺 ${ }^{81}$ に倣いA I C を算定した結 果、コホート数 4 の場合がA I C (53231)が最も小さか ったため、最適なコホート数として 4 を採用した。

従って、図一 2 および図- 3 に示寸ように、8月 2 日の出現頻度分布は 3 つのコホート、8月 6 日の出現 頻度分布は 4 つのコホートから構成されているとして 示した。これらのことより、表一 1 に示寸ように、8 月 2 日から 6 日までの 4 日間で、新たに 2 つのコホー トが発生していたことになる。ただし、8 月 6 日のコ ホート 1 は、平均殼長が約 $210 \mu \mathrm{m}$ であり、このコホ 一トの多くの幼生は既に沈降あるいは着底していて、 観測されたものは残存幼生であると考えられる。

上記の世代解析結果を基に、コホート別の平均成長 速度を推定した。図一 2 と図ー 3 を比較することによ

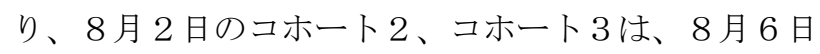
のコホート 1、コホート 2 に対応寸ると考えられるこ

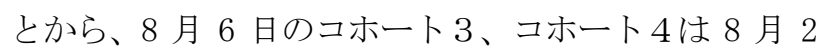
日の観測直後に発生したとものと想定できる。これら の関係から平均成長速度を推定した結果を、表一 1 に 示す。

表一 1 に示すように、成長速度を確定できるのは、 8 月 2 日のコホート $2 、 3$ と 8 月 6 日の $1 、 2$ とから であり、これらの平均值を求めると平均成長速度は 
$17.0 \mu \mathrm{m}$ になる。以下では、平均成長速度は $17 \mu \mathrm{m} /$ day として取り扱った。

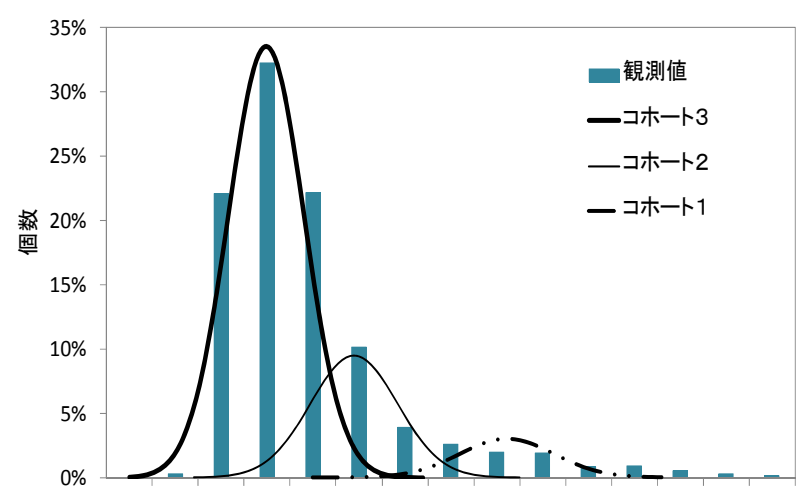

$\begin{array}{llllllllllllll}100 & 110 & 120 & 130 & 140 & 150 & 160 & 170 & 180 & 190 & 200 & 210 & 220 & 230\end{array}$ 款長 $(\mu \mathrm{m})$

図ー2 コホート抽出(8月2日)

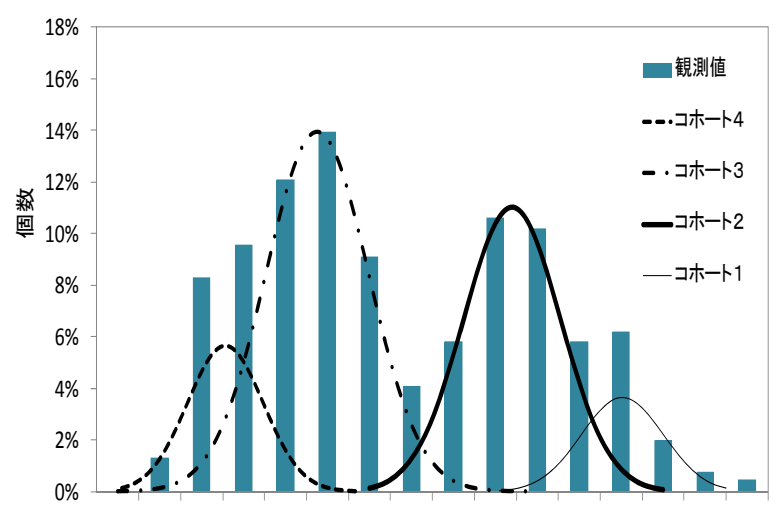

100110120130140150160170180190200210220230240 款長 $(\mu m)$

図ー3 コホート抽出(8月6日)

表一 1 成長速度算定結果

\begin{tabular}{|c|c|c|c|}
\hline 8月2日 & 8月6日 & $\begin{array}{c}\text { 成長速度 } \\
(\mu \mathrm{m} / \mathrm{day}) \\
\end{array}$ & 備考 \\
\hline コホート1 & - & 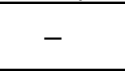 & 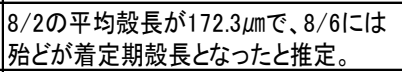 \\
\hline コホート2 & コホート1 & 17.9 & $\begin{array}{l}\text { 8/2の平均殼長が } 138.9 \mu \mathrm{m}, 8 / 6 \text { の平均 } \\
\text { 殻長が } 210.3 \mu \mathrm{m} \text { で4日間成長したため成 } \\
\text { 長速度が } 17.9 \mu \mathrm{m} / \text { dayとなつた。 } \\
\end{array}$ \\
\hline \multirow[t]{3}{*}{ コホート3 } & コホート2 & 16.1 & $\begin{array}{l}\text { 8/2の平均殼長が } 119.8 \mu \mathrm{m}, 8 / 6 \text { の平均 } \\
\text { 殼長が } 184 \mu \mathrm{m} \text { 作 } 4 \text { 日間成長したたた成長 } \\
\text { 速度が } 16.1 \mu \mathrm{m} / \text { dayとなよた。 }\end{array}$ \\
\hline & コホート3 & 17.9 以上 & 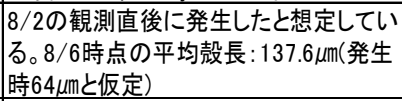 \\
\hline & コホート4 & 12. 9 以上 & $\begin{array}{l}\text { 8/2の観測直後に発生したものと想定し } \\
\text { ている。 } \\
\text { (発生時64 } 64 \text { m時点の仮定) }\end{array}$ \\
\hline
\end{tabular}

\section{4. 成長モデルの再現性の検討}

本研究で構築した簡易成長モデルを用いて、再現性を 検討したものを図ー 4 および 5 に示す。

困一 4 は、8月 2 日に観測された殼長出現頻度分布を コホート 1 を 7 月 27 日に発生させ、コホート 2 を 7 月
29 日、コホート 3 を 7 月 30 日に発生させて再現した ものである。再現計算に用いた個体数は、合計で75,000 個である。また、図一 5 の計算結果は、8月 6 日に観 測された殼長出現頻度分布を、先の 3 回の発生に加え、 更に 8 月 2 日と 8 月 3 日にコホートを発生させて、再 現したものである。再現計算に用いた個体数は、合計 で168,000個である。

図ー4についてみると、最頻度ランクは、計算結果 および観測結果とも $110-120 \mu \mathrm{m}$ で一致し、分布形状 においても、計算結果は観測結果をほぼ再現すること ができたものと考えられる。

同様に、図 -5 は、図 -4 に示寸計算結果の幼生 を更に 4 日間成長させるとともに、先に示したコホ 一ト 3 およびコホート 4 を発生、成長させて求めた 頻度分布を観測結果と比較したものである。図一 5 の頻度分布の特徵は，2 つのピークを持つ双峰分布 をなしていることであるが、計算結果と観測結果は

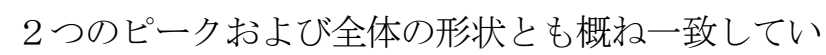
る。従って、本研究で提示した簡易成長モデルの計 算結果は、8月 2 日および 6 日に観測された殼長出 現頻度分布を概ね再現しているものと判断できる。

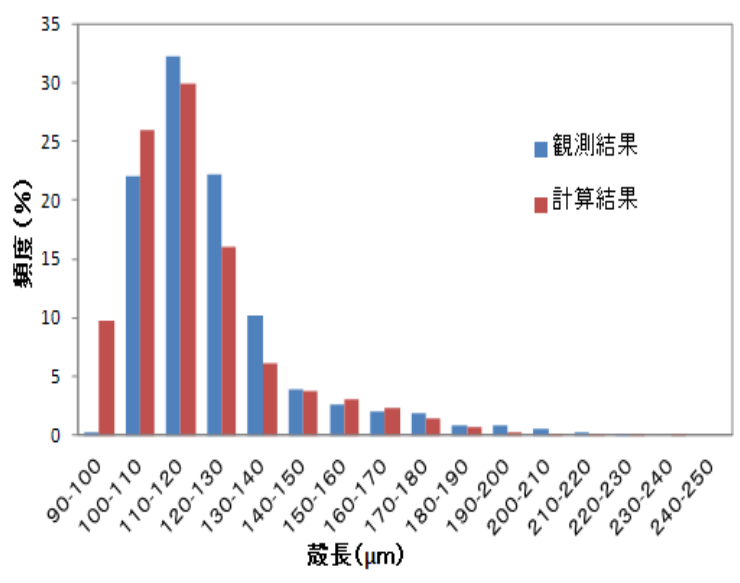

図-4 成長モデル再現結果(8月 2 日)

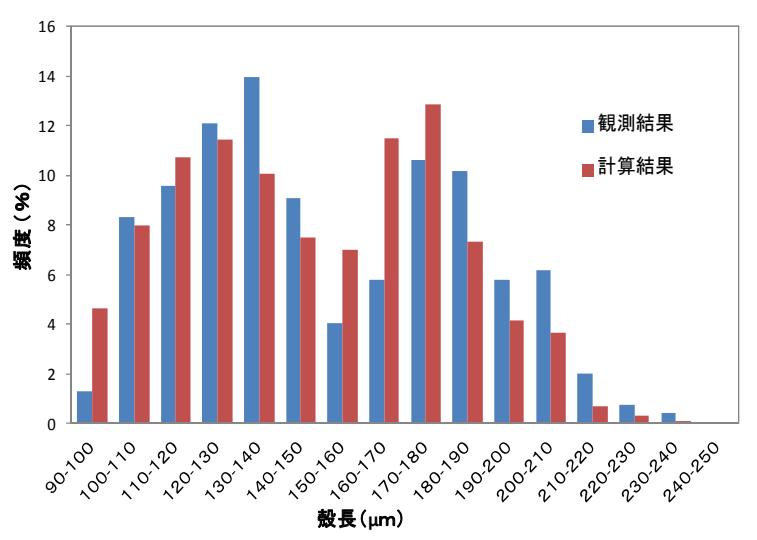

図－5 成長モデル再現結果(8月6日) 


\section{5. 鉛直移動モデルの再現性の検討}

本研究で構築した成長モデルおよび鉛直移動モデルを 用いて、アサリ幼生の鉛直的な出現頻度を再現シミュレ ーションした結果を、図ー 6 および図ー 7 に示す。図一 6 および図一 7 に示す観測值は、粕谷らの観測結果 ${ }^{1)}$ を基に、採取層別（O〜 $4 \mathrm{~m} 、 4 \sim 8 \mathrm{~m} 、 8 \sim 12 \mathrm{~m}$ ）お よび成長段階別（D型幼生期、殼頂期幼生）について出 現率を算定したものである。

図一 6 は、8月 6 日の幼生の鉛直分布を採取層別（0 〜 $4 \mathrm{~m}, 4 \sim 8 \mathrm{~m}, 8 \sim 12 \mathrm{~m}$ ）に再現したものである。 図一 7 は、このときの成長段階をD型幼生期（90～130 $\mu \mathrm{m}$ ） と殼頂期（130～240m） に区分しての再現性を検 討したものである。図一 6 および 7 とも、計算結果は観 測結果を概ね再現していることが確認できる。ただし、 粕谷ら ${ }^{1)}$ の研究では、上層でクラゲなどによるアサリ 幼生の捕食等の影響を推定しているが、本研究では考慮 していない。

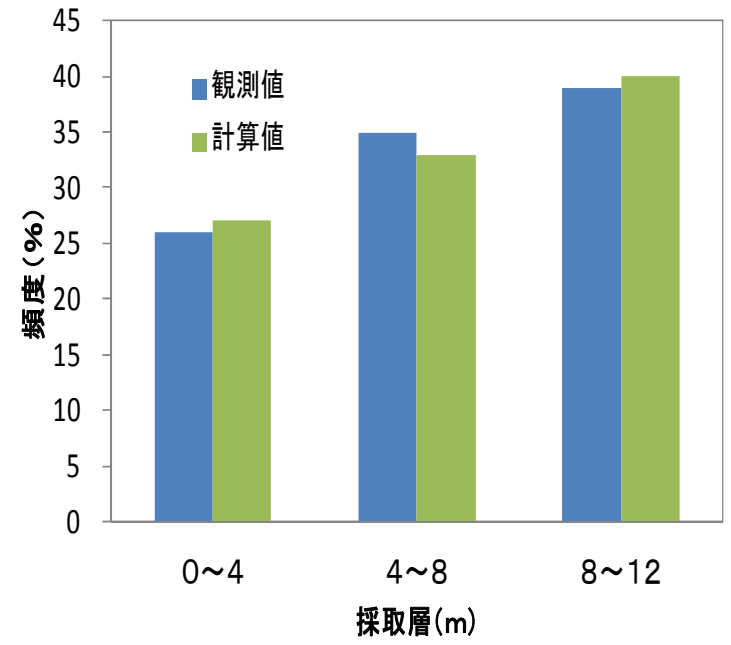

図-6 採取層別出現頻度(8月6日)

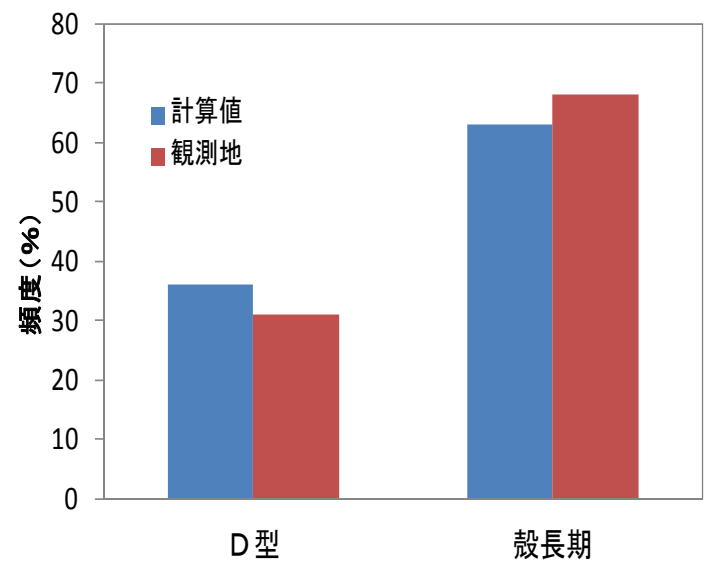

図-7 成長段階別出現頻度(8月6日)
図－8は、8月 6 日の計算結果における各コホート 別の鉛直分布を示す。この結果から、発生が最も新し いコホート 4 は主に海面付近に位置し、成長するに従 い（コホート $3 \longrightarrow$ ーニート $2 \rightarrow コ$ ホト 1) 海面から深 い位置に移行していくことが鉛直移動パターンとして 判別できる。このとき最も古いコホート 1 の個体群は、 平均款長が約 $210 \mu \mathrm{m}$ であり、着底期をむかえている と考えられるため既にほとんどの個体は沈降あるいは 着底している状況が再現されているものと考えられる。

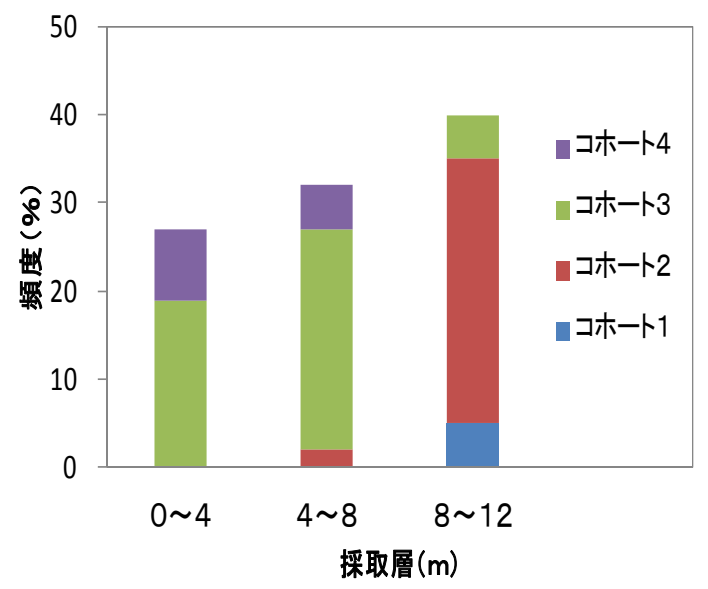

図ー8 コホート別鉛直分布(8月6日)

\section{6. 結 言}

本研究は、まず東京湾におけるアサリ幼生の観測結果 である殼長出現頻度分布を世代解析することによって、 合理的に平均成長速度および幼生の発生日を推定した。 そして、その結果を踏まえて、アサリ幼生の個体差を考 慮した簡易な成長モデルを構築し、殼長出現頻度分布の 観測結果を再現することにより、成長モデルの妥当性を 明らかにした。また、アサリ幼生と海水の密度差を起動 力とする個体差を考慮した鈆直移動モデルを構築し、鈆 直 1 次元の基本的な再現シミュレーションを行いモデル の妥当性を明らかにした。

本研究で実施したアサリ幼生の成長・鉛直移動モデル による現況再現シミュレーションは、東京湾全域を鉛直 1 次元で捉えたものであり、東京湾の流況等は考慮して いない。したがって、今後は、より現実に近い浮遊シミ ュレーションでの適用性を検証するため、本研究で妥当 性を明らかにした成長・鉛直移動モデルを、東京湾にお ける 3 次元的な浮遊シミュレーションに適用していく計 画である。 


\section{参考文献}

1）粕谷智之, 浜口昌巳, 古川恵太, 日向博文 : 夏季東京湾に おけるアサリ浮遊幼生の出現密度の時間的変動, 国土総 合技術研究所報告, 第 8 号, pp. 1-13, 2003

2）日向博文, 戸笠幸嗣: 東京湾におけるアサリ幼生の移流 過程の数值計算, 独立法人水産総合研究センター研究報 告, pp. 59-66, 2005

3）大塚文和 - 鳥飼千晶 - 秋保賢幸 - 弘中真央 - 増田光 一・居駒知樹 : 東京湾を対象にしたアサリネットワー クにおける生息場間影響の定量的評価について,海洋開 発論文集, 第 26 巻, pp. 591-596, 2010.

4）石田基雄, 小笠原桃子, 村上知里, 桃井幹夫, 市川哲也, 鈴木 輝明 : アサリ浮遊幼生の成長に伴う塩分選択行動特性の 変化と鉛直移動様式再現モデル，水産海洋研 究, 69(2), pp. 73-82, 2005.

5）市川哲也, 桃井幹夫, 鈴木輝明, 石田基雄 : リセプターモー ドモデルを利用した造成適地選定手法, 水産工学, Vol. 46, No. 3, pp. 217-222, 2010.

6）瀬戸雅文, 栗山佳丈, 長谷栄一, 小林豊, 荒川久幸 : 波浪場 における二枚貝浮遊幼生の着底・分散機構に関する研究, 海 洋開発論文集, 第 23 号, pp. 453-458, 2007.

7) 堤裕昭, 田中雅生 : 多毛類の個体群動態の調査解析法 （マイクロ・コンピュータを使用した体長の計測から世
代解析まで），日本ベントス研究会誌, No. 31, pp. 1828, 1987.

8) 赤嶺達郎 : Polymodal な度数分布を正規分布一分解する BASIC プログラムの検討, 日水研報告, 35, pp. 129-160, 1985.

9) 赤嶺達郎：水産資源のデー夕解析入門, 恒星社恒星閣,初 版, 2010.

10) Solidoro,C.,Pastres,R.,Melaku Canu,D.,Pellizzato,M.and Rossi,R. : Modelling the growth of Tapes philippinarum in Northem Adriatic lagoons, Mar.Ecol.Prog.Ser., Vol.199, 2000

11）小沼晋, 五島勇樹, 中村由行 : 成長モデルを用いた東京湾 盤洲干潟での二枚貝による懸濁物除去量の推定, 海岸工 学論文集,第 49 巻, pp. 1126-1130, 2002.

12）花町優次, 東博紀, 樋渡武彦, 水野知巳, 村上正吾, 木幡邦 男 : 成長モデルを用いた伊勢湾伊勢地区におけるアサリ 資源量の変動要因の推定，水工学論文集、第 54 号, pp. 1603-1608, 2010.

13）鳥羽光晴 : アサリ幼生の成長速度と水温の関係, 千葉水 試研報, No. 50, pp. 17-20, 1992.

14）鳥羽光晴他:東京湾船橋地先におけるアサリの生殖周期, 日水誌, 59(1), pp. 15-22, 1993.

\title{
A STUDY ON VERTICAL MOVEMENT MODEL OF PLANKTONIC LARVAE OF CLAM RUDITAPES PHILIPPINARUM IN TOKYO BAY
}

\author{
Fumikazu OTSUKA, Toshimasa KAWANISHI and Koichi MASUDA
}

In this paper, by analysis of generation structure of population of created from observation results of larvae of the clam Ruditapes Philippinarum in Tokyo Bay, average growth rate and the spawning date of larvae was estimated in a rational manner. We could create a simplified growth model taking into account the individual differences of the larvae of clam Ruditapes Philippinarum in Tokyo Bay, and prove the validity of the growth model reproducing the results of the observations shown in distribution of frequency of appearance of larvae of different shell lengths. Also, we created a vertical movement model taking into account the individual differences with the difference of density between the sea water and the larvae serving as the impetus and proved the validity of this model by conducting a basic vertical reproduction simulation. 